\title{
Interventions to improve communication between people with dementia and nursing staff during daily nursing care
}

Citation for published version (APA):

Machiels, M., Metzelthin, S. F., Hamers, J. P. H., \& Zwakhalen, S. M. G. (2017). Interventions to improve communication between people with dementia and nursing staff during daily nursing care: A systematic review. International Journal of Nursing Studies, 66, 37-46. https://doi.org/10.1016/j.ijnurstu.2016.11.017

Document status and date:

Published: 01/01/2017

DOI:

10.1016/j.ijnurstu.2016.11.017

Document Version:

Publisher's PDF, also known as Version of record

\section{Document license:}

Taverne

Please check the document version of this publication:

- A submitted manuscript is the version of the article upon submission and before peer-review. There can be important differences between the submitted version and the official published version of record.

People interested in the research are advised to contact the author for the final version of the publication, or visit the DOI to the publisher's website.

- The final author version and the galley proof are versions of the publication after peer review.

- The final published version features the final layout of the paper including the volume, issue and page numbers.

Link to publication

\footnotetext{
General rights rights.

- You may freely distribute the URL identifying the publication in the public portal. please follow below link for the End User Agreement:

www.umlib.nl/taverne-license

Take down policy

If you believe that this document breaches copyright please contact us at:

repository@maastrichtuniversity.nl

providing details and we will investigate your claim.
}

Copyright and moral rights for the publications made accessible in the public portal are retained by the authors and/or other copyright owners and it is a condition of accessing publications that users recognise and abide by the legal requirements associated with these

- Users may download and print one copy of any publication from the public portal for the purpose of private study or research.

- You may not further distribute the material or use it for any profit-making activity or commercial gain

If the publication is distributed under the terms of Article $25 \mathrm{fa}$ of the Dutch Copyright Act, indicated by the "Taverne" license above, 
Review

\title{
Interventions to improve communication between people with dementia and nursing staff during daily nursing care: A systematic review
}

\author{
Mariska Machiels*, Silke F. Metzelthin, Jan P.H. Hamers, Sandra M.G. Zwakhalen \\ Department of Health Services Research, CAPHRI School for Public Health and Primary Care, Maastricht University, Maastricht, The Netherlands
}

\section{A R T I C L E I N F O}

Article history:

Received 15 April 2016

Received in revised form 23 November 2016

Accepted 27 November 2016

\section{Keywords:}

Communication

Dementia

Nursing staff

Daily nursing care

Intervention studies

Systematic review

\begin{abstract}
A B S T R A C T
Background: To provide adequate nursing care it is important for nursing staff to communicate effectively with people with dementia. Due to their limited communication skills, people with dementia have difficulties in understanding communication and expressing themselves verbally. Nursing staff members often report communication difficulties with people with dementia, which emphasises the urgent need for interventions to improve their communication with people in this specific target group.

Objectives: To provide an up-to-date overview of communication interventions that are applicable during daily nursing care activities, irrespective of care setting, and to describe the effects on communication outcomes in people with dementia and nursing staff.

Design: Systematic literature review

Data sources: The Cochrane Library, CINAHL, PsycINFO, and Pubmed databases were searched for all articles published until the 23rd of February 2016.

Review methods: Papers were included, if: (1) interventions focused on communication between nursing staff and people with dementia and were applicable during daily nursing care; (2) studies were (randomised) controlled trials; (3) papers were written in English, Dutch, or German. Data were extracted on content and communication outcomes of interventions, and on methodological quality of the studies. The data extraction form and methodological quality checklist were based on the Method Guidelines for Systematic Reviews for the Cochrane Back Review Group.

Results: Six studies on communication interventions were included. All of the studies incorporated a communication skills training for nursing staff with a broad range in frequency, duration and content. In addition, there was wide variation in the communication outcome measures used. Four studies measured non-verbal communication, all found positive effects on at least some of the communication outcomes. Four studies measured verbal communication, of which three found positive effects on at least one of the measured outcomes. Methodological quality assessment demonstrated a high risk of bias in five of the six studies.

Conclusions: Few studies have been identified with wide variation in interventions and outcome measures. In addition, the methodological shortcomings make it difficult, to draw conclusions about the effectiveness. More research is needed to develop and evaluate communication interventions. Additionally, it is useful to reach consensus on defining and measuring communication.
\end{abstract}

(c) 2017 Elsevier Ltd. All rights reserved.

\section{What is already known about the topic?}

- Communication between people with dementia and nursing staff is important in daily nursing care to provide adequate care.

- Communication with people with dementia may be challenging due to their limited communication skills. Earlier literature

\footnotetext{
* Corresponding author at: Maastricht University, P.O. Box 616, 6200, MD Maastricht, The Netherlands.

E-mail address: m.machiels@maastrichtuniversity.nl (M. Machiels).
}

reviews aimed to identify communication interventions, however, did not focus solely on interventions which are applicable during daily nursing care.

\section{What this paper adds}

- Few communication interventions were identified that are applicable during daily nursing care. All identified interventions incorporated a communication skills training component. 
- Existing interventions show much variation in (1) frequency, duration and content, and (2) outcome measures and reported results. In addition, the identified studies showed methodological shortcomings.

\section{Introduction}

Communication together with care for breathing, eating and drinking, elimination, cleanliness and dressing, mobility, activities, rest, sleep, body temperature, expressing sexuality, care for safety (prevention of complications) and palliative care, belongs to basic nursing care activities, also known as the 'fundamentals of care' (Kitson et al., 2010). Basic nursing care serves nearly all people in their lifetimes and is generic across medical conditions and care settings (Feo and Kitson, 2016; Kitson et al., 2010). Despite its broad application, it is poorly informed by evidence, although this evidence is essential to improve patient functioning, comfort and safety in large populations and in various settings (Zwakhalen et al., under review). The current systematic review focuses on generating evidence to embark upon new research for future intervention studies in communication in daily nursing care with a focus on communication with people with dementia.

Communication with people with dementia can be challenging because of their cognitive impairments (Blair et al., 2007) and decline in verbal communication skills (Ripich, 1994). Communication is defined as an interaction between two (or more) parties, who are reversibly either the sender or receiver of information (Kourkouta and Papathanasiou, 2014). It consists of verbal aspects such as tone and speech, but also of non-verbal aspects like body language and touch (Powell, 2000). In people with dementia both the sending as well as receiving aspect of communication are affected (Ripich, 1994). Communication difficulties may vary among individuals, however, they are most often reflected in an individual's choice of correct words and building complex sentences, difficulties in understanding verbal information, and remembering what has been recently said (Haberstroh et al., 2011; Mendez et al., 2003). However, they are often still able to send and receive non-verbal information or short and easy sentences. In addition, they can talk about things that happened a long time ago (Haberstroh et al., 2011). Furthermore, people with dementia might misinterpret aspects of symbolic information such as metaphors, humorous statements (Fromm and Holland, 1989) and literal statements (Richter et al., 1995; Rousseaux et al., 2010). Because problems mostly occur verbally, people with dementia often express themselves in a non-verbal behavioural way, and understand non-verbal information better as well (Blair et al., 2007; Haberstroh et al., 2011; Savundranayagam et al., 2005). Aggressive and agitated behaviour in people with dementia can also be an attempt to communicate (Blair et al., 2007).

Research shows that nursing staff often lack the skills and knowledge needed to communicate properly (Stans et al., 2013). Understanding the non-verbal behavioural communication and impaired verbal expression of people with dementia can be problematic for nursing staff (Brodaty et al., 2003; Savundranayagam et al., 2005; Small et al., 2000; Wang et al., 2013). In addition, communication is often a low priority because of the workload they experience, and the nursing staff's lack of awareness concerning the importance of communication (Buron, 2008; Stans et al., 2013). This results in short interactions which are mostly task-oriented and mainly occur during nursing care activities (Beerens et al., 2016; Ekman et al., 1991; Grainger, 2004; Ice, 2002; Williams et al., 2009; Wood et al., 2005).

Communication difficulties may have troublesome effects on the quality of daily nursing care (Yorkston et al., 2010) as communication is essential to understand patients' preferences and feelings and to establish their care needs (Candlin and Candlin, 2003; Yorkston et al., 2010). When nursing staff experience difficulties in communicating with people with dementia, a reduction in the interaction rate can be observed (Hairon, 2008). One reason might be that communication difficulties have been shown to increase the stress and burnout levels of nursing staff (Savundranayagam et al., 2005). Stressed nursing staff and the unmet needs of people with dementia in turn may cause an even greater increase in the aggressive and agitated behaviour of people with dementia (Downs and Collins, 2015).

Previous research has shown that dementia education is inadequately preparing nursing staff for daily dementia care (Pulsford et al., 2007; Tsolaki et al., 2010) and for communicating with people with dementia (Beer et al., 2012; Downs et al., 2009). Consequently, more support is suggested to deal with this problem (Hughes et al., 2008; Lee et al., 2013; Page and Hope, 2013). In the past, several systematic reviews have evaluated communication interventions. While Eggenberger et al. (2013) evaluate communication skills training for professional and nonprofessional caregivers in any care setting, the systematic review of Vasse et al. (2010) has a broader scope of interventions and also includes set-time interventions such as walking and talking interventions, cognitive stimulation therapies or activity therapies, though it is not specifically aimed at improving the communication between people with dementia and nursing staff. Another review by McGilton et al. (2009) focuses on communication interventions in residential care settings. However, the interventions are not specifically designed for people with dementia and nursing staff, but for residents and healthcare providers in general. Thus the interventions included are not necessarily applicable during daily nursing care for people with dementia.

To date, no systematic review exists that focuses specifically on communication interventions which are applicable during daily nursing care. 'Applicable during daily nursing care' means that the communication interventions can be applied during regular care moments (e.g. washing or dressing). Therefore, interventions that need extra time such as group therapies or walking-and-talking interventions (also known as set-time interventions) were excluded. Moreover, interventions aimed at improving communication during daily nursing care activities have been shown to be more effective than set-time interventions (Vasse et al., 2010) and may save time and money, which is highly relevant considering the strain on health care caused by ageing societies (Fujisawa and Colombo, 2009). This systematic review will provide an up-to-date description of communication interventions which are applicable during daily nursing care, irrespective of the care setting. Furthermore, it will provide a description of the effects on communication outcomes.

\section{Methods}

A systematic literature review was performed based on the principles of the Cochrane Handbook for reviews (Higgins and Green, 2011). This type of design is used to provide a description of the content and effects of existing communication interventions which are empirically tested.

\subsection{Search strategy}

On 23rd February 2016, the Cochrane, CINAHL, PsycINFO, and Pubmed databases were accessed for intervention studies with any date of publication. The databases were accessed by either title or title and abstract. No limitations in the search time frame were used. Search terms included those related to dementia, communication, and intervention studies: ('dementia' OR 'lewy body' OR 'lewy 
body disease' OR 'vascular dementia' OR 'Alzheimer' OR 'Alzheimer's disease' OR 'frontotemporal dementia' OR 'Dementia'[Mesh]) and ('communication' OR 'communicate' OR 'communicating' OR 'interact' OR 'interacting' OR 'interactions' OR 'conversation' OR 'conversations' OR 'talk' OR 'talking' OR 'contact' OR 'contacting' OR 'Communication' [MeSH]) and ('trial' OR 'experimental' OR 'experiment' OR 'intervention'). This particular strategy was used to search according to title and abstract in the Pubmed database. Search strategies were adapted to every database with the use of mesh terms and synonyms. In Appendix 1 at Supplementary material a detailed overview of the search strategies used can be found.

\subsection{Eligibility criteria}

Studies were included if they met the following criteria: firstly, the study had to evaluate the effectiveness of an intervention that aims to improve communication (verbal and/ or non-verbal) between nursing staff and people with dementia, and therefore needed to measure communication outcomes between people with dementia and the nursing staff. Secondly, the interventions had to be applicable during daily nursing care activities, meaning that nursing staff can apply the intervention at any time during daily care. Thirdly, only full-text articles which were accessible and written in English, Dutch, or German were included. Fourthly, the study design had to be a (randomised) controlled trial.

\subsection{Study screening}

All studies retrieved from the databases were exported to EndNote (version X7). After duplicates were removed, the study selection was performed in three rounds. In each round studies were classified as 'include', 'exclude' or 'uncertain'. 'Uncertain' was scored if insufficient information was available to decide whether the article was to be in- or excluded based on the title or abstract respectively (the article was included for the next round). In the first round, two reviewers (MM, FG) independently assessed the first $10 \%$ of the studies based on title. Differences in the classification of studies were discussed among the two reviewers, until a consensus was reached. The screening of the first $10 \%$ of studies resulted in a level of agreement of $58 \%$. The following $10 \%$ of studies resulted in a level of agreement of $80 \%$, which was prespecified as the threshold level of agreement to continue the screening by one reviewer (MM) only. Titles were assessed based on the presence of relevant terms in the title. Second, the abstracts of the titles included were accessed and screened using the same strategy. In the first $10 \%$ of the abstract screening, an agreement level of $72 \%$ was reached. The screening of the second $10 \%$ resulted in a sufficient level of agreement (81\%). If an abstract was not available, the article was excluded. Of the abstracts which did not provide enough information to be able to make an informed decision on relevancy for this review, the full text was searched. Third, the remaining studies were screened by one reviewer (MM) based on the full text. A citation and reference check was performed on all full-text articles to ensure that no relevant articles were missed. All studies that were classified as 'included' or 'uncertain' were discussed with two other reviewers (SM, SZ) until a consensus was reached. The number of articles, and reason for exclusion were documented in all rounds.

\subsection{Methodological quality assessment}

The studies included were assessed according to methodological quality by one reviewer (MM) and discussed with a second reviewer (SM) using the Method Guidelines for Systematic
Reviews for the Cochrane Back Review Group (Furlan et al., 2015). The checklist consists of 13 items related to the method of randomisation and concealing of treatment allocation (if applicable), blinding (patient, care provider, outcome assessor), avoidance of co-interventions, acceptability of compliance, acceptability of drop-out rate, timing of outcome-assessment, absence/presence of selective reporting, and similarity of groups (Furlan et al., 2015, 2009). The items concerning group similarity and drop-out were rated separately for nursing staff and people with dementia, resulting in two extra items. Items were scored with a 'yes', 'no', or 'unsure'. The checklist for methodological quality assessment used for this review can be found in Appendix 2 at Supplementary material. Differences in assessment between the two reviewers were discussed until a consensus was reached, and if needed, a third reviewer (SZ) was involved. If an item was not applicable for a study (e.g. randomisation in a non-randomised trial), 'not applicable' was scored. If the information provided in the articles was insufficient to assess a certain item, the first author (and last author) of the article was contacted for more information. If additional information was still lacking, an 'unsure' was scored for this particular item. A 'yes' was considered to contribute to the methodological quality of the study. A study was considered to have a relatively low risk of bias when at least half the items were scored with 'yes'; that is in the case where at least eight items were scored with 'yes'. No recommendations regarding cut-off points for low or high risk of bias are given in Furlan et al. (2015). However, this decision was based on the second last version of the Method Guidelines for Systematic Reviews for the Cochrane Back Review Group (Furlan et al., 2009). The methodological quality assessment was not used as inclusion criteria for study screening; rather, the methodological quality assessment was used to give a description of the methods used and it was taken into consideration when the reported effects were interpreted.

\subsection{Data extraction and analysis}

Based on the Cochrane Handbook for Reviews, and the Method Guidelines for Systematic Reviews for the Cochrane Back Review Group (Furlan et al., 2015; Higgins and Green, 2011) a data extraction form was developed. Data were extracted based on publication year, author, participants, study methods, comparison groups, study setting, characteristics of interventions, communication outcomes measured and instruments used, results of communication outcomes, key points of conclusion, and discussion (Furlan et al., 2015; Higgins and Green, 2011). Data extraction forms were completed by one reviewer (MM) and discussed with a second reviewer (SM) until a consensus was reached. The authors of the articles were asked to provide the protocol for the intervention for more information. The data extraction form used for this review can be found in Appendix C at Supplementary material.

\section{Results}

\subsection{Search results}

The search strategy resulted in 3815 hits. After removing duplicates ( $n=1537), 2278$ potentially relevant titles were identified. The title screening resulted in 539 potentially relevant abstracts. The abstract screening resulted in potentially relevant 37 full-text articles. From the 37 full-text articles, six articles were included for data extraction. Most articles were excluded during the search due to the intervention not being focused on communication $(n=1469)$. Detailed information on the reasons for exclusion is provided in Fig. 1. 


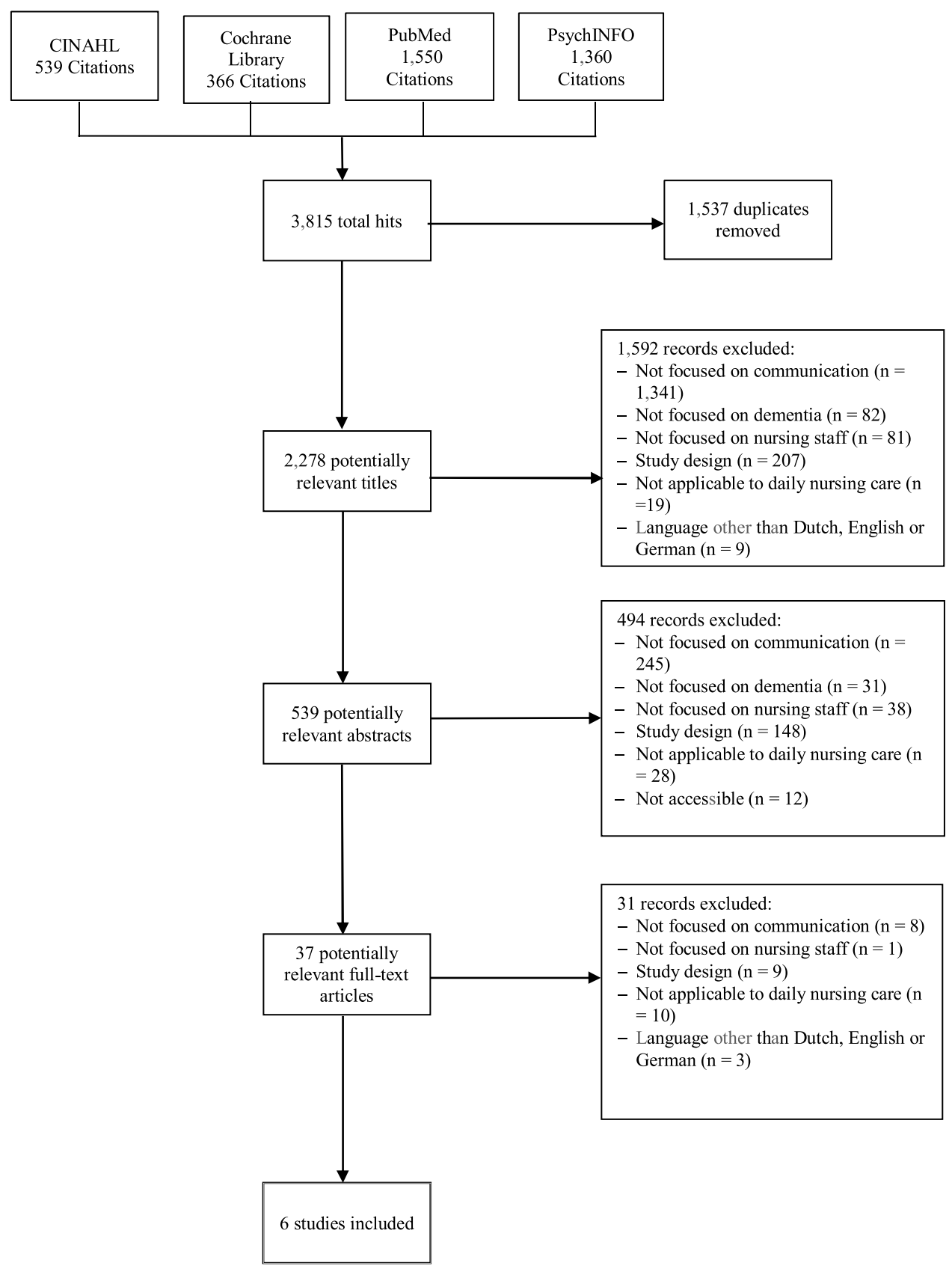

Fig. 1. Literature search flow diagram.

\subsection{Methodological quality}

Table 1 provides the results of the methodological quality assessment. One study was considered to have a low risk of bias with a quality score of eight (van Weert et al., 2005). The other studies scored four or lower indicating a high risk of bias. The low scores for the studies are mainly due to a lack of information in the articles. The times 'unsure' was scored ranged from four to 11. Of

Table 1

Methodological quality

\begin{tabular}{|c|c|c|c|c|c|c|c|c|c|c|c|c|c|c|c|c|}
\hline Author (year) & 1 & 2 & 3 & 4 & 5 & $6 a$ & $6 b$ & 7 & 8 & $9 a$ & $9 b$ & 10 & 11 & 12 & 13 & Total score \\
\hline Wells et al. (2000) & $\mathrm{U}$ & $\mathrm{U}$ & $\mathrm{U}$ & - & + & + & - & $\mathrm{U}$ & $\mathrm{U}$ & - & + & $\mathrm{U}$ & $\mathrm{U}$ & $\mathrm{U}$ & $\mathrm{U}$ & 3 \\
\hline Dijkstra et al. (2002) & - & - & - & - & - & $\mathrm{U}$ & $\mathrm{U}$ & $\mathrm{U}$ & $\mathrm{U}$ & $\mathrm{U}$ & $\mathrm{U}$ & + & $\mathrm{U}$ & + & - & 2 \\
\hline Magai et al. (2002) & $\mathrm{U}$ & $\mathrm{U}$ & $\mathrm{U}$ & - & + & - & + & $\mathrm{U}$ & $\mathrm{U}$ & $\mathrm{U}$ & - & $\mathrm{U}$ & + & + & - & 4 \\
\hline van Weert et al. (2005) & + & + & $\mathrm{U}$ & - & + & $\mathrm{U}$ & + & $\mathrm{U}$ & $\mathrm{U}$ & + & - & + & + & $\mathrm{U}$ & + & 8 \\
\hline Haberstroh et al. (2009) & NA & NA & $\mathrm{U}$ & - & $\mathrm{U}$ & - & - & $\mathrm{U}$ & $\mathrm{U}$ & $\mathrm{U}$ & $\mathrm{U}$ & $\mathrm{U}$ & $\mathrm{U}$ & + & - & 1 \\
\hline Sprangers et al. (2015) & NA & NA & $\mathrm{U}$ & - & - & + & + & $\mathrm{U}$ & $\mathrm{U}$ & $\mathrm{U}$ & $\mathrm{U}$ & + & $\mathrm{U}$ & + & - & 4 \\
\hline
\end{tabular}

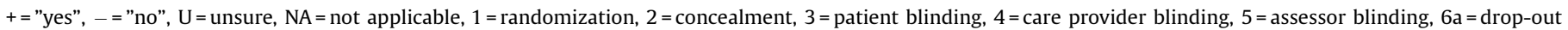

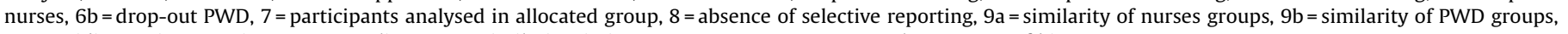
$10=$ avoiding co-interventions, $11=$ compliance, 12 = similarity timing outcome assessment, $13=$ other sources of bias. 
the six studies of which the authors were contacted, two authors responded and provided additional information (Dijkstra et al., 2002; Sprangers et al., 2015).

\subsection{Description of studies and content of interventions}

In Table 2, an overview of the included studies is given. All interventions took place at long-term care facilities, but there was a variation in the study designs. In all studies, a control group was compared with one or more intervention groups. The sample size of the studies, however, ranged from 26 people with dementia (Sprangers et al., 2015) and six nursing staff members (Haberstroh et al., 2009) to 121 people with dementia and 121 nursing staff members (van Weert et al., 2005). One study only focused on nursing assistants (Dijkstra et al., 2002), and another five studies did not report on the qualification level of the nursing staff. All studies incorporated communication skills training for nursing staff members, and all interventions were aimed at enhancing the communication skills of nursing staff that could be used during all daily nursing care activities. The reported duration of the training ranged from five sessions of 20-30 min (Wells et al., 2000) to four sessions, each of four hours (van Weert et al., 2005). It was unclear, however, if the training concerned planned or delivered sessions. Furthermore, no information was given regarding the time at which the sessions were given. Two studies also did not report on the number/duration of sessions (Dijkstra et al., 2002; Sprangers et al., 2015). The communication skills training consisted of lectures, hands-on training and/or group discussions. In addition, two studies implemented a communication-enhancing instrument (for example, the use of memory books), in the communication skills training which was meant to support nursing staff in improving their communication with people with dementia (Dijkstra et al., 2002; Haberstroh et al., 2009). Furthermore, two multi-component interventions were identified that had a broader scope than just communication. In the study of van Weert et al. (2005), a Multi-Sensory Stimulation (MSS) snoezelen intervention was integrated in 24-h dementia care. MSS is the stimulation of the senses by light, sound, feeling, smell, and taste (Holtkamp et al., 1997), and is implemented to communicate with people with dementia during daily nursing care activities. Next to training in snoezelen, nursing staff members received communication skills training (van Weert et al., 2005). The study of Wells et al. (2000) included an educational programme on residents' and caregivers' interaction behaviour, the communication component of which focused on informing nursing staff about the social abilities of people with dementia and how to interact with them.

\subsection{Content of communication skills trainings}

The identified papers provide limited information on the content of the interventions, which subsequently hampers the identification of intervention components, as the theoretical framework of the interventions is often inadequately described. For example, it is not clear on which behaviour change theories or communication theories the interventions were based. Furthermore, it remains unclear which activities were performed and how

Table 2

Description of studies and interventions.

\begin{tabular}{|c|c|c|c|c|c|c|}
\hline $\begin{array}{l}\text { Author (year), } \\
\text { country }\end{array}$ & Design & Setting & Sample & Study groups & Intervention components & $\begin{array}{l}\text { Number and duration of } \\
\text { training sessions }\end{array}$ \\
\hline $\begin{array}{l}\text { Wells et al. } \\
\text { (2000), } \\
\text { Canada }\end{array}$ & $\mathrm{RCCT}$ & $\begin{array}{l}\text { Four support } \\
\text { units from one } \\
\text { geriatric centre }\end{array}$ & $\begin{array}{l}40 \text { people with } \\
\text { dementia } \\
40 \text { nursing staff } \\
\text { members }\end{array}$ & Intervention & $\begin{array}{l}\text { Training in social abilities of PWD and how to } \\
\text { interact with PWD by the use of } 12 \text { interventions } \\
\text { on social abilities }\end{array}$ & $\begin{array}{l}5 \text { sessions }(20-30 \mathrm{~min} \\
\text { each })+ \text { reinforcement } \\
\text { sessions after } \\
\text { implementation until end } \\
\text { of study }\end{array}$ \\
\hline $\begin{array}{l}\text { Dijkstra et al. } \\
\text { (2002), USA }\end{array}$ & RCT & $\begin{array}{l}\text { Eight long-term } \\
\text { care facilities }\end{array}$ & $\begin{array}{l}66 \text { people with } \\
\text { dementia } \\
24 \text { nursing staff } \\
\text { members }\end{array}$ & $\begin{array}{l}\text { Control } \\
\text { Intervention }\end{array}$ & $\begin{array}{l}\text { Usual care } \\
\text { Training verbal communication and use of memory } \\
\text { books. The memory book was used as visual signal } \\
\text { during care activities, to reduce problem behaviour } \\
\text { and as a conversation support instrument } \\
\text { Usual care }\end{array}$ & $\begin{array}{l}1 \mathrm{~h} \text { lecture and } 2-4 \text { weeks } \\
\text { hands-on training during } \\
\text { care, of which duration is not } \\
\text { specified }\end{array}$ \\
\hline \multirow[t]{2}{*}{$\begin{array}{l}\text { Magai et al. } \\
\text { (2002), USA }\end{array}$} & RCT & $\begin{array}{l}\text { Three long-term } \\
\text { care facilities }\end{array}$ & $\begin{array}{l}99 \text { people with } \\
\text { dementia } \\
20 \text { nursing staff } \\
\text { members }\end{array}$ & Intervention & $\begin{array}{l}\text { Training in non-verbal communication } \\
\text { and recognizing emotions }\end{array}$ & 101 -h sessions with lectures \\
\hline & & & & $\begin{array}{l}\text { Active control } \\
\text { Control }\end{array}$ & $\begin{array}{l}\text { Dementia care training } \\
\text { Usual care }\end{array}$ & \\
\hline $\begin{array}{l}\text { van Weert } \\
\text { et al. } \\
\text { (2005), The } \\
\text { Netherlands }\end{array}$ & RCCT & $\begin{array}{l}12 \text { wards from } \\
\text { six long-term } \\
\text { care facilities }\end{array}$ & $\begin{array}{l}121 \text { people with } \\
\text { dementia } \\
121 \text { nursing } \\
\text { staff members }\end{array}$ & Intervention & $\begin{array}{l}\text { Training in verbal and non-verbal communication, and } \\
\text { snoezelen. It was taught to integrate snoezelen in daily } \\
\text { nursing care activities by the use of a snoezelplan }\end{array}$ & $\begin{array}{l}44 \text {-h in-service sessions and } \\
\text { homework }+2 \text { guidance } \\
\text { sessions after } \\
\text { implementation }\end{array}$ \\
\hline \multirow[t]{3}{*}{$\begin{array}{l}\text { Haberstroh } \\
\text { et al. } \\
\text { (2009), } \\
\text { Germany }\end{array}$} & NRCT & $\begin{array}{l}\text { Six long-term } \\
\text { care facilities }\end{array}$ & $\begin{array}{l}30 \text { people with } \\
\text { dementia } \\
6 \text { nursing staff } \\
\text { members }\end{array}$ & $\begin{array}{l}\text { Control } \\
\text { Intervention } 1\end{array}$ & $\begin{array}{l}\text { Usual care } \\
\text { Training in verbal and non-verbal communication } \\
\text { with PWD next to a self-evaluation instrument to } \\
\text { encourage improving communication }\end{array}$ & $\begin{array}{l}18 \text {-h seminar for each } \\
\text { intervention group }\end{array}$ \\
\hline & & & & Intervention $2^{\mathrm{a}}$ & $\begin{array}{l}\text { Training in verbal and non-verbal communication } \\
\text { with colleagues }\end{array}$ & \\
\hline & & & & $\begin{array}{l}\text { Combination } \\
\text { Control }\end{array}$ & $\begin{array}{l}\text { Combination of the two interventions } \\
\text { Usual care }\end{array}$ & \\
\hline \multirow[t]{2}{*}{$\begin{array}{l}\text { Sprangers } \\
\text { et al. } \\
\text { (2015), The } \\
\text { Netherlands }\end{array}$} & NRCT & $\begin{array}{l}\text { Two wards from } \\
\text { one long-term } \\
\text { care facility }\end{array}$ & $\begin{array}{l}26 \text { people with } \\
\text { dementia } \\
24 \text { nursing staff } \\
\text { members }\end{array}$ & Intervention & $\begin{array}{l}\text { Training in verbal communication skills, in which } \\
\text { negative speech skills were discouraged and positive } \\
\text { speech skills encouraged }\end{array}$ & $\begin{array}{l}1-2 \text { sessions of lectures } \\
\text { (duration of sessions not } \\
\text { specified) }\end{array}$ \\
\hline & & & & Control & Usual care & \\
\hline
\end{tabular}

NRCCT $=$ Non-Randomized Controlled Trial, RCT $=$ Randomized Controlled Trial, RCCT = Randomized Cluster Controlled Trial, NRCT = Non-Randomized Controlled Trial.

a Not relevant for this review. 
these activities were assumed to provide the expected behavioural change. Since no additional information, for example through the use of a protocol study, could be found or was available, only a limited content description could be made.

The intervention of Magai et al. (2002) was focused on enhancing the non-verbal communication skills of nursing staff. The training covered topics concerning basic emotions, expression of emotions, personal emotional triggers and recognising emotions. Furthermore, behaviour that could have negative influences on the communication with people with dementia was discussed with the nursing staff (Magai et al., 2002).

In Sprangers et al. (2015) nursing staff members were trained in verbal communication skills, such as short and general instructions, biographical statements and positive speech. Furthermore, they were trained to limit their use of ineffective communication skills such as using multiple instructions and negative speech. During training, nursing staff were individually observed when interacting with residents during their care routines and received feedback on the quality of their interactions (Sprangers et al., 2015).

In the study of Dijkstra et al. (2002) nursing staff members were trained in verbal communication skills, such as the use of short sentences and instructions during care activities, giving positive feedback, and talking about the interests of the people with dementia. In addition, nursing staff members made use of memory books as a tool for communicating with people with dementia, and as a visual signal for a care activity. Moreover, nursing staff members were instructed to use the memory books to reduce problem behaviours. For example, when someone was repetitively asking about his or her son, the personalised memory with a picture of that son could be shown with the date of the next visit. The memory books contained information about the personal interests of the people with dementia, their experience and history, along with visual components such as pictures (Dijkstra et al., 2002).

The study of Haberstroh et al. (2009) contained two interventions. One intervention focused on the communication skills of nursing staff with colleagues. This intervention was focused on encouraging nursing staff to discuss experiences and problems with residents with each other (not relevant for this study). The other intervention focused on communication with people with dementia, in which nursing staff members were trained in nonverbal and verbal communication. For example, they were trained on picking up on signals from people with dementia and learning to understand those signals. Furthermore, the nursing staff members were encouraged to increase communication and interaction with people with dementia. A third group received a combination of both interventions. In addition to the communication skills training, the half of the nursing staff who were in the combination group was taught to use a self-evaluation instrument to raise awareness regarding their communication skills (Haberstroh et al., 2009).

In the study of van Weert et al. (2005) snoezelen was used to adapt the communication of the nursing staff to the capabilities of those with dementia. Nursing staff were trained to integrate the practical skills of snoezelen into $24 \mathrm{~h}$ nursing care (for example, using the life history of residents, taking a person-centred approach by writing a snoezelen plan for each resident, and applying sensory stimuli). Furthermore, nursing staff members received training in verbal and non-verbal communication with people with dementia. Topics included learning to pick up on signals and how to interpret them, showing affection and empathy, supporting people with dementia in their responsiveness (for example, by giving the person enough time to respond), and validating the point of view of those with dementia. Furthermore, nursing staff members were discouraged from trying to teach people with dementia or to test their cognitive abilities (van Weert et al., 2005).

In the communication skills training of Wells et al. (2000) nursing staff members were trained to increase their social interaction with people with dementia. The programme was focused on retaining the social and self-care abilities of people with dementia. Topics covered the social abilities of people with dementia, such as, for example, how to start and maintain a conversation, and how to receive and give attention. Twelve interventions related to social abilities were taught to the nursing staff, such as the use of conventional greetings, the use of memory books, providing appropriate cues, and using objects as motor cues (Wells et al., 2000).

\subsection{Outcome measurements and effects}

Two of the six studies measured both verbal and non-verbal communication (Haberstroh et al., 2009; van Weert et al., 2005), whereas four studies measured either only non-verbal (Magai et al., 2002; Wells et al., 2000) or verbal communication (Dijkstra et al., 2002; Sprangers et al., 2015). In three studies (Haberstroh et al., 2009; Sprangers et al., 2015; Wells et al., 2000) data were collected using questionnaires. One study (Dijkstra et al., 2002) used tape-recordings, another study (van Weert et al., 2005) used a combination of video-recordings and questionnaires, and lastly, one study (Magai et al., 2002) combined questionnaires with semistructured interviews with people with dementia. There was much variation in communication outcomes and instruments used. Only in two studies (Sprangers et al., 2015; Wells et al., 2000) was the outcome measurement assessed during morning care. In the other four studies, outcome measurement was evaluated during the general daily nursing care. An overview of the communication outcomes and instruments used is presented in Table 3.

\subsubsection{Effects of interventions on verbal communication}

All three studies which measured verbal communication of people with dementia (Dijkstra et al., 2002; Haberstroh et al., 2009; van Weert et al., 2005) reported on at least one outcome with statistically significant effects on improving communication. Four studies measured verbal communication of the nursing staff (Dijkstra et al., 2002; Haberstroh et al., 2009; Sprangers et al., 2015; van Weert et al., 2005), of which two showed positive effects on nursing staff outcomes (Dijkstra et al., 2002; van Weert et al., 2005). Detailed information on the effects of these interventions is presented in Table 3.

\subsubsection{Effects of interventions on non-verbal communication}

All studies that measured non-verbal communication of people with dementia (Magai et al., 2002; van Weert et al., 2005; Wells et al., 2000) reported on at least one outcome with statistically significant effects. Finally, both studies that assessed the effects of the intervention on the non-verbal communication of nursing staff (van Weert et al., 2005; Wells et al., 2000) demonstrated favourable effects on the non-verbal communication of nursing staff. The effects of the interventions on non-verbal communication are presented in Table 3.

\section{Discussion}

This systematic review aimed to provide an up-to-date description of communication interventions which are applicable during daily nursing care irrespective of the care setting, and to describe their effects on communication outcomes. The focus on communication during nursing care activities is highly relevant as a fundamental of care (Kitson et al., 2010). In addition, communication is an important component in the 
Table 3

Results of interventions and instruments used.

\begin{tabular}{|c|c|c|c|c|c|}
\hline Author(s) (year) & Sample & General outcome & Instrument used & Specific outcome & $\begin{array}{l}\text { Reported effects }{ }^{*} \text { (p- } \\
\text { value) }\end{array}$ \\
\hline \multirow{7}{*}{$\begin{array}{l}\text { Wells et al. } \\
\text { (2000) }\end{array}$} & \multirow{3}{*}{$\begin{array}{l}\text { People with dementia } \\
(\mathrm{n}=40)\end{array}$} & \multirow{3}{*}{$\begin{array}{l}\text { Non-verbal } \\
\text { communication }\end{array}$} & \multirow[t]{3}{*}{ Modified Interaction Behaviour Measure ${ }^{1}$} & Personal attending & Yes $(\mathrm{p}<0.05)$ \\
\hline & & & & Calm/functional behaviour & Yes $(\mathrm{p}<0.03)$ \\
\hline & & & & Agitation & Yes $(\mathrm{p}<0.03)$ \\
\hline & \multirow[t]{4}{*}{ Nursing staff $(n=40)$} & \multirow{4}{*}{$\begin{array}{l}\text { Non-verbal } \\
\text { communication }\end{array}$} & \multirow[t]{4}{*}{ Interaction Behaviour Measure ${ }^{2}$} & Relevance & Yes $(\mathrm{p}<0.01)$ \\
\hline & & & & Personal attending & Yes $(\mathrm{p}<0.03)$ \\
\hline & & & & Relaxed behaviour & Yes $(\mathrm{p}<0.03)$ \\
\hline & & & & Social/flexible behaviour & Yes $(\mathrm{p}<0.02)$ \\
\hline \multirow{15}{*}{$\begin{array}{l}\text { Dijkstra et al. } \\
\text { (2002) }\end{array}$} & \multirow{9}{*}{$\begin{array}{l}\text { People with dementia } \\
(n=66)\end{array}$} & \multirow[t]{9}{*}{ Verbal communication } & \multirow{9}{*}{ Conversation tape-recordings } & Number of utterances & Yes $(\mathrm{p}<0.01)$ \\
\hline & & & & Number of words & No \\
\hline & & & & Unique words & Yes $(\mathrm{p}<0.01)$ \\
\hline & & & & Information units & Yes $(\mathrm{p}<0.01)$ \\
\hline & & & & Global coherence & Yes $(\mathrm{p}<0.01)$ \\
\hline & & & & Local coherence & Yes $(\mathrm{p}<0.01)$ \\
\hline & & & & Empty phrases & No \\
\hline & & & & Repetitions & $\mathrm{No}^{* * *}$ \\
\hline & & & & Indefinite words & Yes $(\mathrm{p}<0.01)$ \\
\hline & \multirow[t]{6}{*}{ Nursing staff $(n=30)$} & \multirow[t]{6}{*}{ Verbal communication } & \multirow[t]{6}{*}{ Conversation tape-recordings } & Number of utterances & No \\
\hline & & & & Total number of questions & No \\
\hline & & & & Total number of prompts & No \\
\hline & & & & Repetitions & No \\
\hline & & & & Encouragements & Yes $(\mathrm{p}<0.02)$ \\
\hline & & & & Cues & Yes $(\mathrm{p}<0.001)$ \\
\hline \multirow{3}{*}{$\begin{array}{l}\text { Magai et al. } \\
\text { (2002) }\end{array}$} & \multirow{3}{*}{$\begin{array}{l}\text { People with dementia } \\
(n=91)\end{array}$} & \multirow{3}{*}{$\begin{array}{l}\text { Non-verbal } \\
\text { communication }\end{array}$} & \multirow[t]{3}{*}{ Semi-structured interview } & Symptomatology & No \\
\hline & & & & $\begin{array}{l}\text { Facial expression of positive } \\
\text { emotions }\end{array}$ & Yes $(\mathrm{p}<0.05)$ \\
\hline & & & & $\begin{array}{l}\text { Facial expression of negative } \\
\text { emotions }\end{array}$ & No \\
\hline \multirow{14}{*}{$\begin{array}{l}\text { van Weert et al. } \\
\text { (2005) }\end{array}$} & \multirow{6}{*}{$\begin{array}{l}\text { People with dementia } \\
(\mathrm{n}=121)\end{array}$} & Non-verbal & Video-recordings & Eye-contact & Yes $(\mathrm{p}<0.05)$ \\
\hline & & communication & & Smiling & Yes $(\mathrm{p}<0.01)$ \\
\hline & & Verbal communication & Roter Interaction Analysis System ${ }^{3}$ & $\begin{array}{l}\text { Affective positive } \\
\text { communication }\end{array}$ & No \\
\hline & & & & $\begin{array}{l}\text { Affective negative } \\
\text { communication }\end{array}$ & Yes $(\mathrm{p}<0.05)$ \\
\hline & & & & $\begin{array}{l}\text { Instrumental positive } \\
\text { communication }\end{array}$ & No \\
\hline & & & & $\begin{array}{l}\text { Instrumental negative } \\
\text { communication }\end{array}$ & No \\
\hline & Nursing staff $(n=121)$ & Non-verbal & Video-recordings & Eye-contact & Yes $(\mathrm{p}<0.01)$ \\
\hline & & communication & & Affective touch & Yes $(\mathrm{p}<0.01)$ \\
\hline & & & & Instrumental touch & No \\
\hline & & & & Smiling & Yes $(\mathrm{p}<0.01)$ \\
\hline & & Verbal communication & Roter Interaction Analysis System ${ }^{3}$ & $\begin{array}{l}\text { Affective positive } \\
\text { communication }\end{array}$ & Yes $(\mathrm{p}<0.01)$ \\
\hline & & & & $\begin{array}{l}\text { Affective negative } \\
\text { communication }\end{array}$ & Yes $(\mathrm{p}<0.05)$ \\
\hline & & & & $\begin{array}{l}\text { Instrumental positive } \\
\text { communication }\end{array}$ & Yes $(\mathrm{p}<0.01)$ \\
\hline & & & & $\begin{array}{l}\text { Instrumental negative } \\
\text { communication }\end{array}$ & Yes $(\mathrm{p}<0.01)$ \\
\hline $\begin{array}{l}\text { Haberstroh et al. } \\
\text { (2009) }\end{array}$ & $\begin{array}{l}\text { People with dementia } \\
(\mathrm{n}=30)\end{array}$ & $\begin{array}{l}\text { Verbal and non-verbal } \\
\text { communication }\end{array}$ & Positive Response Schedule ${ }^{4}$ & Communicative ability & Yes $(\mathrm{p}<0.05)$ \\
\hline & Nursing staff $(n=6)$ & $\begin{array}{l}\text { Verbal and non-verbal } \\
\text { communication }\end{array}$ & $\begin{array}{l}\text { Fragenbogen zur beruflichen Kompetenz } \\
\text { in der Altenpflege }{ }^{5}\end{array}$ & $\begin{array}{l}\text { Social competence } \\
\text { (interaction with PWD) }\end{array}$ & No \\
\hline Sprangers et al. & Nursing staff $(n=24)$ & Verbal communication & The Observation form of General & Total speech & No \\
\hline (2015 & & & Communication & Neutral speech & No \\
\hline & & & The Communication Skills Checklist ${ }^{6}$ & Positive speech & No \\
\hline & & & & Negative speech & No \\
\hline & & & & Biographical statements & No \\
\hline & & & & Call by name & No \\
\hline & & & & Announce activity & No \\
\hline & & & & Short instructions & No \\
\hline & & & & General instructions & No \\
\hline & & & & Multiple instructions & No \\
\hline
\end{tabular}

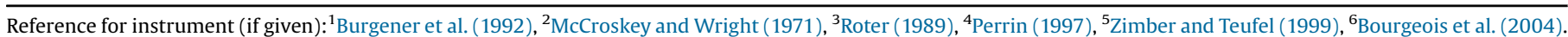

${ }^{*}$ If in favour of intervention group.

** Connotations of $\mathrm{p}$-values are converted into a $\mathrm{p}<\mathrm{x}$ equation for uniformity reasons. Next to that, all values are rounded to two decimals.

${ }^{* * *}$ The author of this article reported this effect as significant with a p-value of 0.05 . The authors of this review report effects with a p-value lower than 0.05 .

establishment of the nurse-patient relationship which contributes to meaningful engagement with the patient, and to fulfilling their social and care needs (Wiechula et al., 2016). Six intervention studies were identified, all of which incorporated communication skills training for nursing staff. In addition, all studies were conducted in institutionalised longterm care facilities. Which makes sense as most people with an advanced stage of dementia and related communication difficulties live in long-term care facilities. Nevertheless, it is assumed that (elements of) the identified interventions can be 
integrated into daily nursing care in other settings as well. Based on this systematic review, it is not possible to draw conclusions about the effectiveness of the identified interventions for several reasons. First, the interventions differed considerably in frequency, duration, and content. There were single communication skills training, communication skills training combined with the use of tools, and multi-component interventions of which a communication skills training was a component, identified. The reported duration of the training ranged from five sessions of $20-30$ min to four sessions, each lasting for four hours. Second, there was considerable variation in the chosen outcome measures. In the studies both verbal and non-verbal communication were measured, making use of both quantitative and qualitative data collection methods. In addition, communication as the primary outcome was not defined. Although five out of six studies show statistically significant effects on at least one communication outcome (verbal or nonverbal), it is questionable how clinically relevant these results are and whether the intervention was successful in reaching the study's aim. Third, the methodological quality assessment demonstrated a high risk of bias in five of the six studies.

The identified interventions in this systematic review aimed to improve communication by focusing on the behaviour of nursing staff. However, the description of the content of the interventions was limited; it is not clear what the programme model of the interventions looks like. A programme model displays: (1) underlying theory-based assumptions, (2) planned work, and (3) intended results (Kellogg Foundation, 2004). First, the studies poorly described the assumptions and theoretical framework of their interventions. Second, the specific activities (planned work) within the intervention could not be identified. Third, with regard to the intended results, many studies measure individual components of communication (e.g. short sentences), proxies of communication (e.g. agitation) and their long-term effects on people with dementia and nursing staff (e.g. well-being, work satisfaction). However, the identified studies do not explicitly report if communication itself has actually improved.

Based on this systematic review it is not possible to identify intervention components that are more promising than others with regard to changing nursing staff behaviour. However, based on the behavioural change literature it is known that an essential prerequisite for behavioural change is to understand why people (do not) engage in the behaviour of interest (Kok et al., 2015). Furthermore, barriers and enablers for the targeted behaviour, such as knowledge, skills or social influences, have to be identified (Michie et al., 2009). Based on this analysis, which is preferably conducted together with various stakeholders, the underlying behavioural change theory needs to be identified (Grol et al., 2013a). In addition, intervention developers need to take into account that there is variation in the effectiveness of strategies. For example, educational materials (e.g. written recommendations) have been shown to be the least effective, whereas outreach visits (e.g. hands-on training) (Wensing et al., 2013), feedback and reinforcement (Bandura, 1986) have been shown to be more promising. Furthermore, interventions such as experiences (Schmidt and De Volder, 1984), learning needs (Festinger, 1954), learning style (Grol et al., 2013b) and the phase of behavioural change (Bartholomew et al., 2011; Merriam, 1996; Norman and Schmidt, 1992; Prochaska et al., 2008) have to match the characteristics of potential users. Last but not least, professionals/nursing staff learn best when the content suits the problems of their daily practice.

This systematic review has shown that there is insufficient evidence concerning how the communication between nursing staff and people with dementia can be improved. Consequently, nursing staff have little guidance concerning how to actually change their behaviour to improve their communication and fulfil the needs of those with dementia. There are several theorybased strategies which provide support for improving verbal as well as non-verbal communication, such as speaking clearly, trying to grab the attention of people with dementia before communicating, and using active listening techniques (e.g. making eye-contact) (Downs and Collins, 2015), but their effectiveness with respect to communication outcomes remains unknown. Nevertheless, communication is essential to provide person-centred basic nursing care in which client preferences are clear and are taken into account (Kitson et al., 2013a,b). Previous research has shown that the fundamentals of care are often overlooked while new care standards and innovations are rapidly implemented. When the essence of nursing care is falling short, all other initiatives will fail as well (Feo and Kitson, 2016).

This review has several limitations. First, we limited our search to interventions that were applicable during daily nursing care. Consequently, promising set-time interventions such as walking and talking interventions (Cott et al., 2002; Friedman and Tappen, 1991) and 'Talking Mats' (Murphy et al., 2007) were excluded. This is, however, at the same time a strength of this systematic review, as the identified interventions can be applied during the time that is already spent on care, in contrast to set-time interventions which cost extra time and money. This is highly relevant as we face an ageing society worldwide and shortages in both financial resources and the workforce (Fujisawa and Colombo, 2009; National Institute on Aging, National Institutes of Health, \& World Health Organization, 2011). Second, another limitation of this review is that studies that did not measure communication outcomes were excluded. Consequently, several potentially promising communication-related interventions were not taken into account. Examples of these are the study of McCallion et al., 1999, and person-centred care (PCC) interventions (Chenoweth et al., 2014). Third, this systematic review used four different databases to search for relevant papers. If more databases or sources other than databases were used, more relevant papers could possibly have been identified. Last, the aim of this study was to evaluate interventions which aim to improve communication between nursing staff and people with dementia during daily nursing care. Narrowing the communication down to interactions during nursing care activities may limit the ability to grasp the complete picture of communication between nursing staff and people with dementia. Nevertheless, most interactions occur during nursing care activities.

The fact that many studies measure communication in completely different ways, or do not measure communication at all, hits upon the key issue when it comes to communication research. Communication with people with dementia seems to be an unclear and incomprehensible concept. Consequently, it is challenging to both improve it and to measure it. This is further reflected in the diversity of the reported study results in this systematic review. Therefore, a consensus regarding defining and measuring communication in dementia care is desirable. Additionally, when conducting future studies that aim to evaluate communication interventions it is suggested that the focus should be on daily nursing care activities. In particular, it is during these activities that one-to-one interactions between nursing staff and residents occur and that communication is most discernible. This was also shown to be a strong facet of earlier research, (Sloane et al., 2004). In addition, the development and implementation of interventions have to be based on theory and need to be clearly described. Last but not least, there is a need for high-quality intervention studies using communication outcome measures which are validated and widely used, as also recommended by McGilton et al. (2009). 


\section{Conflict of interests}

There are no conflicts of interest.

\section{Acknowledgements}

We would like to thank Fabian Groven> (FG) who was involved as reviewer. Furthermore, this study is conducted with financial support from ZonMw (grant \#80-80705-98-025).

\section{Appendix A. Supplementary data}

Supplementary data associated with this article can be found, in the online version, at http://dx.doi.org/10.1016/j.ijnurstu.2016. 11.017.

\section{References}

Bandura, A., 1986. Social Foundations of Thought and Action: A Social Cognitive Theory. Prentice-Hall, Inc., Englewood Cliffs, NJ.

Bartholomew, L.K., Parcel, G.S., Kok, G., Gottlieb, N.H., 2011. Planning Health Promotion Programs: An Intervention Mapping Approach. John Wiley \& Sons, San Franciso, CA.

Beer, L.E., Hutchinson, S.R., Skala-Cordes, K.K., 2012. Communicating with patients who have advanced dementia: training nurse aide students. Gerontol. Geriat Educ. 33 (4), 402-420. doi:http://dx.doi.org/10.1080/02701960.2012.702165.

Beerens, H.C., de Boer, B., Zwakhalen, S.M.G., Tan, F.E.S., Ruwaard, D., Hamers, J.P.H., Verbeek, H., 2016. The association between aspects of daily life and quality of life of people with dementia living in long-term care facilities: a momentary assessment study. Int. Psychogeriatr. 28 (8), 1323-1331. doi:http://dx.doi.org $10.1017 /$ s 1041610216000466 FirstView 1-9.

Blair, M., Marczinski, C.A., Davis-Faroque, N., Kertesz, A., 2007. A longitudinal study of language decline in Alzheimer's disease and frontotemporal dementia. J. Int. Neuropsychol. Soc. 13 (02), 237-245. doi:http://dx.doi.org/10.1017/ S1355617707070269.

Bourgeois, M.S., Dijkstra, K., Burgio, L.D., Allen, R.S., 2004. Communication skills training for nursing aides of residents with dementia: the impact of measuring performance. Clin. Gerontol. 27 (1-2), 119-138.

Brodaty, H., Draper, B., Low, L.F., 2003. Nursing home staff attitudes towards residents with dementia: strain and satisfaction with work. J. Adv. Nurs. 44 (6), 583-590. doi:http://dx.doi.org/10.1046/j.030-2402.2003.02848.x.

Burgener, S.C., Jirovec, M., Murrell, L., Barton, D., 1992. Caregiver and environmental variables related to difficult behaviors in institutionalized, demented elderly persons. J. Gerontol. 47 (4), P242-P249.

Buron, B., 2008. Levels of personhood: a model for dementia care. Geriatr. Nur. (Lond.) 29 (5), 324-332.

Candlin, C.N., Candlin, S., 2003. Health care communication: a problematic site for applied linguistic research. Annu. Rev. Appl. Linguist. 23, 134-154.

Chenoweth, L., Forbes, I., Fleming, R., King, M.T., Stein-Parbury, J., Luscombe, G., Brodaty, H., 2014. PerCEN: A cluster randomized controlled trial of personcentered residential care and environment for people with dementia. Int Psychogeriatr. 26 (7), 1147-1160. doi:http://dx.doi.org/10.1017/ S1041610214000398 Retrieved from: http://onlinelibrary.wiley.com/o/ cochrane/clcentral/articles/497/CN-00992497/frame.html.

Cott, C.A., Dawson, P., Sidani, S., Wells, D., 2002. The effects of a walking/talking program on communication, ambulation, and functional status in residents with Alzheimer disease. Alzheimer Dis. Assoc. Disord. 16 (2), 81-87. doi:http:/ dx.doi.org/10.1097/00002093-200204000-00005.

Dijkstra, K., Bourgeois, M., Burgio, L., Allen, R., 2002. Effects of a communication intervention on the discourse of nursing home residents with dementia and their nursing assistants. J. Med. Speech-Lang. Pathol. 10 (2), 143-157.

Downs, M., Collins, L., 2015. Person-centred communication in dementia care. Nurs. Stand. 30 (11), 37-41.

Downs, M., Capstick, A., Baldwin, P.C., Surr, C., Bruce, E., 2009. The role of higher education in transforming the quality of dementia care: dementia studies at the University of Bradford. Int. Psychogeriatr. 21 (Suppl. S1), S3-S15. doi:http://dx. doi.org/10.1017/s1041610209008837.

Eggenberger, E., Heimerl, K., Bennett, M.I., 2013. Communication skills training in dementia care: a systematic review of effectiveness, training content, and didactic methods in different care settings. Int. Psychogeriatr. 25 (03), 345-358. doi:http://dx.doi.org/10.1017/S1041610212001664.

Ekman, S.L., Norberg, A., Viitanen, M., Winblad, B., 1991. Care of demented patients with severe communication problems. Scand. J. Caring Sci. 5 (3), 163-170.

Feo, R., Kitson, A., 2016. Promoting patient-centred fundamental care in acute healthcare systems. Int. J.Nurs. Stud. 57, 1-11. doi:http://dx.doi.org/10.1016/j. ijnurstu.2016.01.006.

Festinger, L., 1954. A theory of social comparison processes. Hum. Relat. 7 (2), 117 140. doi:http://dx.doi.org/10.1177/001872675400700202.

Friedman, R., Tappen, R.M., 1991. The effect of planned walking on communication in Alzheimer's disease. J. Am. Geriatr. Soc. 39 (7), 650-654.
Fromm, D., Holland, A.L., 1989. Functional communication in Alzheimer's disease. J. Speech Hear. Disord. 54 (4), 535-540.

Fujisawa, R., Colombo, F., 2009. The Long-Term Care Workforce: Overview and Strategies to Adapt Supply to a Growing Demand (1815-2015). OECD Publishing, Paris, France doi:http://dx.doi.org/10.1787/225350638472.

Furlan, A.D., Pennick, V., Bombardier, C., van Tulder, M., 2009. 2009 Updated method guidelines for systematic reviews in the Cochrane Back Review Group. Spine 34 (18), 1929-1941.

Furlan, A.D., Malmivaara, A., Chou, R., Maher, C.G., Deyo, R.A., Schoene, M., Van Tulder, M.W., 2015. 2015 Updated method guideline for systematic reviews in the Cochrane back and neck group. Spine 40 (21), 1660-1673.

Grainger, K., 2004. Communication and the institutionalized elderly. Handbook of Communication and Aging Research, , pp. 479-497.

Grol, R., Ouwens, M., Wollersheim, H., 2013a. Planning and Organizing the Change Process Improving Patient Care. John Wiley \& Sons, Ltd., pp. 64-76.

Grol, R., Wensing, M., Bosch, M., Hulscher, M., Eccles, M., 2013b. Theories on Implementation of Change in Healthcare Improving Patient Care. John Wiley \& Sons, Ltd., Chisester, UK, pp. 18-39.

Haberstroh, J., Neumeyer, K., Schmitz, B., Pantel, J., 2009. Development and evaluation of a training program for nursing home professionals to improve communication in dementia care. Zeitschrift für Gerontologie und Geriatrie 42 (2), 108-116. doi:http://dx.doi.org/10.1007/s00391-008-0527-x.

Haberstroh, J., Neumeyer, K., Johannes, P., 2011. Kommunikation bei Demenz: Ein Ratgeber für Angehörige und Pflegende. Springer-Verlag, Berlin.

Hairon, N., 2008. Improving communication skills in care of those with dementia. Nurs. Times 104 (23), 19-20.

Higgins, J.P.T., Green, S., 2011. Cochrane Handbook for Systematic Reviews of Interventions Version 5 1.0. [updated March 2011]. .

Holtkamp, C.C.M., Kragt, K., van Dongen, M.C.J.M., van Rossum, E., Salentijn, C., 1997. Effecten van snoezelen op het gedrag van demente ouderen. Tijdschr. Gerontol. Geriatr. 28 (3), 124-128.

Hughes, J., Bagley, H., Reilly, S., Burns, A., Challis, D., 2008. Care staff working with people with dementia: training, knowledge and confidence. Dementia 7 (2), 227-238. doi:http://dx.doi.org/10.1177/1471301208091159.

Ice, G.H., 2002. Daily life in a nursing home: has it changed in 25 years? J. Aging Stud. 16 (4), 345-359.

Kellogg Foundation, W.K., 2004. Logic model development guide. Retrieved from Michigan, USA.

Kitson, A., Conroy, T., Wengstrom, Y., Profetto-McGrath, J., Robertson-Malt, S., 2010. Defining the fundamentals of care. Int. J. Nurs. Pract. 16 (4), 423-434. doi:http:// dx.doi.org/10.1111/j.1440-172X.2010.01861.x.

Kitson, A., Dow, C., Calabrese, J.D., Locock, L., Athlin, Å.M., 2013a. Stroke survivors' experiences of the fundamentals of care: a qualitative analysis. Int. J. Nurs. Stud. 50 (3), 392-403. doi:http://dx.doi.org/10.1016/j.ijnurstu.2012.09.017.

Kitson, A., Marshall, A., Bassett, K., Zeitz, K., 2013b. What are the core elements of patient-centred care? A narrative review and synthesis of the literature from health policy, medicine and nursing. J. Adv. Nurs. 69 (1), 4-15. doi:http://dx.doi. org/10.1111/j.136-2648.2012.06064.X

Kok, G., Gottlieb, N.H., Peters, G.Y., Mullen, P.D., Parcel, G.S., Ruiter, R.A., Bartholomew, L.K., 2015. A taxonomy of behaviour change methods: an intervention mapping approach. Health Psychol. Rev. 1-16 [Epub ahead of print].

Kourkouta, L., Papathanasiou, I.V., 2014. Communication in nursing practice. Mater. Sociomed. 26 (1), 65-67.

Lee, J., Hui, E., Kng, C., Auyeung, T.W., 2013. Attitudes of long-term care staff toward dementia and their related factors. Int. Psychogeriatr. 25 (1), 140-147. doi: http://dx.doi.org/10.1017/s1041610212001512.

Magai, C., Cohen, C.I., Gomberg, D., 2002. Impact of training dementia caregivers in sensitivity to nonverbal emotion signals. Int. Psychogeriatr. 14 (1), 25-38.

McCallion, P. Toseland, R.W., Lacey, D., Banks, S., 1999. Educating nursing assistants to communicate more effectively with nursing home residents with dementia. Gerontologist 39 (5), 546-558. doi:http://dx.doi.org/10.1093/geront/ 39.5.546.

McCroskey, J.C., Wright, D.W., 1971. The development of an instrument for measuring interaction behavior in small groups. Speech Monogr. 38 (4), 335340. doi:http://dx.doi.org/10.1080/03637757109375728.

McGilton, K.S., Boscart, V., Fox, M., Sidani, S., Rochon, E., Sorin-Peters, R., 2009. A systematic review of the effectiveness of communication interventions for health care providers caring for patients in residential care settings. Worldviews Evid.-Based Nurs. 6 (3), 149-159. doi:http://dx.doi.org/10.1111/j.1741-6787. 2009.00155.x.

Mendez, M.F., Clark, D.G., Shapira, J.S., Cummings, J.L., 2003. Speech and language in progressive nonfluent aphasia compared with early Alzheimer's disease. Neurology 61 (8), 1108-1113.

Merriam, S.B., 1996. Updating our knowledge of adult learning. J. Contin. Educ. Health Prof. 16 (3), 136-143. doi:http://dx.doi.org/10.1002/chp.4750160303.

Michie, S., Fixsen, D., Grimshaw, J.M., Eccles, M.P., 2009. Specifying and reporting complex behaviour change interventions: the need for a scientific method. Implement. Sci. 4 (40) doi:http://dx.doi.org/10.1186/1748-5908-4-40.

Murphy, J., Gray, C.M., Cox, S., 2007. Communication and Dementia: How Talking Mats Can Help People with Dementia to Express Themselves. Joseph Rowntree Foundation, York.

National Institute on Aging, National Institutes of Health, \& World Health Organization, 2011. Global health and ageing. Retrieved from Bethesda.

Norman, G.R., Schmidt, H.G., 1992. The psychological basis of problem-based learning: a review of the evidence. Acad. Med. 67 (9), 557-565. 
Page, S., Hope, K., 2013. Towards new ways of working in dementia: perceptions of specialist dementia care nurses about their own level of knowledge, competence and unmet educational needs. J. Psychiatr. Ment. Health Nurs. 20 (6), 549-556. doi:http://dx.doi.org/10.1111/jpm.12029.

Perrin, T., 1997. The positive response schedule for severe dementia. Aging Ment. Health 1 (2), 184-191.

Powell, J.A., 2000. Communication interventions in dementia. Rev. Clin. Gerontol. 10 (2), 161-168. doi:http://dx.doi.org/10.1017/S0959259800000277.

Prochaska, J.O., Redding, C.A., Evers, K.E., 2008. The Transtheoretical Model and stages of change, In: Glanz, K., Rimer, B.K., Viswanath, K. (Eds.), Health Behavior and Health Education: Theory, Research, and Practice. 4th ed. Jossey-Bass, San Francisco, pp. 97-121.

Pulsford, D., Hope, K., Thompson, R., 2007. Higher education provision for professionals working with people with dementia: a scoping exercise. Nurse Educ. Today 27 (1), 5-13.

Richter, J.M., Roberto, K.A., Bottenberg, D.J., 1995. Communicating with persons with Alzheimer's disease: experiences of family and formal caregivers. Arch. Psychiatr. Nurs. 9 (5), 279-285. doi:http://dx.doi.org/10.1016/S0883-9417(95) 80047-6.

Ripich, D.N., 1994. Functional communication with AD patients: a caregiver training program. Alzheimer Dis. Assoc. Disord. 8, 95-109.

Roter, D., 1989. The Roter Method of Interaction Process Analysis. Johns Hopkins University, Baltimore.

Rousseaux, M., Sève, A., Vallet, M., Pasquier, F., Mackowiak-Cordoliani, M.A., 2010. An analysis of communication in conversation in patients with dementia. Neuropsychologia 48 (13), 3884-3890. doi:http://dx.doi.org/10.1016/j.neuropsychologia.2010.09.026.

Savundranayagam, M.Y., Hummert, M.L., Montgomery, R.J.V., 2005. Investigating the effects of communication problems on caregiver burden. J. Gerontol. Ser. B: Psychol. Sci. Soc. Sci. 60 (1), S48-S55. doi:http://dx.doi.org/10.1093/geronb/60.1. S48.

Schmidt, H.G., De Volder, M., 1984. Tutorials in Problem-Based Learning Assen. Van Gorcum, The Netherlands.

Sloane, P.D., Hoeffer, B., Mitchell, C.M., McKenzie, D.A., Barrick, A.L., Rader, J., Koch, G. G., 2004. Effect of person-centered showering and the towel bath on bathingassociated aggression, agitation, and discomfort in nursing home residents with dementia: a randomized, controlled trial. J. Am. Geriatr. Soc. 52 (11), 1795-1804. doi:http://dx.doi.org/10.1111/j.1532-5415.2004.52501.x.

Small, J.A., Geldart, K., Gutman, G.,2000. Communication between individuals with dementia and their caregivers during activities of daily living. Am. J. Alzheimer's Dis. Dement. 15 (5), 291-302.

Sprangers, S., Dijkstra, K., Romijn-Luijten, A., 2015. Communication skills training in a nursing home: effects of a brief intervention on residents and nursing aides. Clin. Interv. Aging 10, 311-319. doi:http://dx.doi.org/10.2147/cia.s73053.
Stans, S.E.A., Dalemans, R., de Witte, L., Beurskens, A., 2013. Challenges in the communication between 'communication vulnerable' people and their social environment: an exploratory qualitative study. Patient Educ. Couns. 92 (3), 302 312. doi:http://dx.doi.org/10.1016/j.pec.2013.05.021.

Tsolaki, M., Papaliagkas, V., Anogianakis, G., Bernabei, R., Emre, M., Frolich, L., Rikkert, M.O., 2010. Consensus statement on dementia education and training in Europe. J. Nutr. Health Aging 14 (2), 131-135.

Vasse, E., Vernooij-Dassen, M., Spijker, A., Rikkert, M.O., Koopmans, R., 2010. A systematic review of communication strategies for people with dementia in residential and nursing homes. Int. Psychogeriatr. 22 (02), 189-200. doi:http:// dx.doi.org/10.1017/S1041610209990615.

van Weert, J.C.M., van Dulmen, A.M., Spreeuwenberg, P.M.M., Ribbe, M.W., Bensing, J.M., 2005. Effects of snoezelen, integrated in $24 \mathrm{~h}$ dementia care, on nursepatient communication during morning care. Patient Educ. Couns. 58 (3), $312-$ 326. doi:http://dx.doi.org/10.1016/j.pec.2004.07.013.

Wang, J., Hsieh, P., Wang, C., 2013. Long-term care nurses' communication difficulties with people living with dementia in Taiwan. Asian Nurs. Res. 7 (3), 99-103. doi:http://dx.doi.org/10.1016/j.anr.2013.06.001.

Wells, D.L., Dawson, P., Sidani, S., Craig, D., Pringle, D., 2000. Effects of an abilitiesfocused program of morning care on residents who have dementia and on caregiversJ. Am. Geriatr. Soc. 48 (4), 442-449. . Retrieved from http:/ onlinelibrary.wiley.com/o/cochrane/clcentral/articles/739/CN-00277739/ frame.html.

Wensing, M., Fluit, C., Grol, R., 2013. Educational strategies Improving Patient Care. John Wiley \& Sons, Ltd., Chisester, UK, pp. 197-209.

Wiechula, R., Conroy, T., Kitson, A.L., Marshall, R.J., Whitaker, N., Rasmussen, P., 2016 Umbrella review of the evidence: what factors influence the caring relationship between a nurse and patient? J. Adv. Nurs. 72 (4), 723-734. doi:http://dx.doi. org/10.1111/jan.12862.

Williams, K.N., Herman, R., Gajewski, B., Wilson, K., 2009. Elderspeak communication: impact on dementia care. Am. J. Alzheimer's Dis. Dement. 24 (1), 11-20. doi:http://dx.doi.org/10.1177/1533317508318472.

Wood, W., Harris, S., Snider, M., Patchel, S.A., 2005. Activity situations on an Alzheimer's disease special care unit and resident environmental interactions, time use, and affect. Am. J. Alzheimer's Dis. Dement. 20 (2), 105-118. doi:http:// dx.doi.org/10.1177/153331750502000210.

Yorkston, K.M., Bourgeois, M.S., Baylor, C.R., 2010. Communication and aging. Phys Med. Rehabil. Clin. N. Am. 21 (2), 309-319. doi:http://dx.doi.org/10.1016/j pmr.2009.12.011.

Zimber, A., Teufel, S., 1999. Wie gut bin ich eigentlich. Altenpflege 10, 45-48.

Zwakhalen, et al. (under review). Essential nursing care: most provided, least evidence. Time to change: the Basic Care Revisited research program. 